\title{
Co-Modification With Mesenchymal Stem Cells Membrane and PDA Prevents Fe304-Induced Pulmonary Toxicity in Micevia AMPK-ULK1 Axis
}

\section{Hua Yao}

China-Japan Union Hospital of Jilin University

Jun Yan

China-Japan Union Hospital of Jilin University

\section{Pu Shao}

China-Japan Union Hospital of Jilin University

\section{Yuzhuo Wang}

China-Japan Union Hospital of Jilin University

\section{Tianxin Liu}

School and Hospital of Stomatology, Jilin University

\section{Jinlan Jiang}

China-Japan Union Hospital of Jilin University

Te Liu ( $\sim$ iamliute@jlu.edu.cn )

China-Japan Union Hospital of Jilin University https://orcid.org/0000-0003-4697-7792

\section{Research}

Keywords: mesenchymal stem cells membrane, Fe304, Autophagy, Adiposis

Posted Date: January 19th, 2021

DOI: https://doi.org/10.21203/rs.3.rs-147495/v1

License: (c) This work is licensed under a Creative Commons Attribution 4.0 International License. Read Full License 


\section{Abstract}

Background: $\mathrm{Fe}_{3} \mathrm{O}_{4}$ nanoparticles are widely used in the diagnosis and treatment of diseases, but the toxicity should not be ignored. It has been reported that PDA modification can reduce the toxicity of $\mathrm{Fe}_{3} \mathrm{O}_{4}$ and increase the biocompatibility. However, a better modification method is still worth studying. We have developed a new method to coat $\mathrm{Fe}_{3} \mathrm{O}_{4} @ P D A$ nanoparticles with mesenchymal stem cells membrane (MSCM) and evaluated the lung toxicity of the modified particles to mice.

Result: We found that MSCM modification significantly reduced the lung injury induced by $\mathrm{Fe}_{3} \mathrm{O}_{4}$ nanoparticles in mice. Compared with $\mathrm{Fe}_{3} \mathrm{O}_{4} @$ PDA nanoparticles, co-modification with MSCM and PDA modification significantly reduced autophagy and apoptosis of mouse lung tissue, and reduced the activation of autophagy pathway AMPKULK1 axis. Thus, co-modification with MSCM and PDA prevents $\mathrm{Fe}_{3} \mathrm{O}_{4}$-induced pulmonary toxicity in mice by inhibiting the AMPK-ULK1 derived autophagy.

Conclusion: MSCM coated $\mathrm{Fe}_{3} \mathrm{O}_{4} @ P D A$ nanoparticles were demonstrated to prevent lung damage from autophagy and reduce the toxicity of iron oxide nanomaterials. The co-modification of PDA and MSCM can improve the biocompatibility and facilitate their further bioapplication.

\section{Background}

Nano-sized $\mathrm{Fe}_{3} \mathrm{O}_{4}$ has many specialproperties, such as superparamagnetism, which enables it to be used as magnetic resonance imaging contrast agents[1], targeted drug delivery systems[2]and hyperthermic agents[3]. However, the negative effects of nano-sized $\mathrm{Fe}_{3} \mathrm{O}_{4}$ in practical application should not be ignored. Some studies have shown that metal oxides, including $\mathrm{Fe}_{2} \mathrm{O}_{3}, \mathrm{Fe}_{3} \mathrm{O}_{4}$ and $\mathrm{ZnO}$ can induce autophagy in vivo[4, 5]. In addition, it has been reported that in the process of drug treatment with nanoparticles, nanoparticles not only induce autophagy of specific lesions, but also induce autophagy of normal cells, leading to poisoning of healthy cells[6].

As the most abundant organ of blood flow, pulmonary macrophages absorb nanoparticles through endocytosis and cause lung damage[7-9].Nano titanium exposure induces dose- and size-dependent cytotoxicity on human epithelial lung cells[10].Nano $\mathrm{NiO}$ can lead to lung injury in rats which may be related with nitrative stress reaction based on pulmonary inflammation[11].Little is known about the role of $\mathrm{Fe}_{3} \mathrm{O}_{4}$ in pulmonary toxicity, northe mechanisms of $\mathrm{Fe}_{3} \mathrm{O}_{4}$-induced autophagy.

Before being used in medicine, the nanoparticles must be modified with some molecular layers to produce biocompatibility. Dopamine is one of the main pigments of melanin, which is rich in neurotransmitter in human body. This neurotransmitter can self-aggregate to form polydopamine (PDA) under specific conditions. Because of the high biocompatibility and biodegradability, PDA has been widely used in the camouflage of nanoparticles and various biomedical applications[12].PDA-coated magnetic nanostructureshave good thermal stability, photothermal conversion efficiencies, $\mathrm{pH}$ responsiveness,biocompatibility and low genotoxicity[13-15].Some studies have shown that the use of PDA modification can significantly improve the biocompatibility of $\mathrm{Fe}_{3} \mathrm{O}_{4}$, but it still shows a certain degree of cytotoxicity. Therefore, the development of new modification methods is an urgent need for the clinical application of $\mathrm{Fe}_{3} \mathrm{O}_{4}$. 
The natural stem cell membrane camouflaged nanoparticles were used as new drug delivery carriers[16]. The new drug delivery carrier first separated the mesenchymal stem cell membrane, and then obtained the nanoparticles camouflaged by the physical extrusion method. By passing the "passport" to these nanomaterials, the immune system avoids external rejection of particles, thereby avoiding the occurrence of immune responses[17]. The nanoparticles camouflaged by stem cell membrane have the advantages of uniform particle size, good stability and biocompatibility.

Herein, wehave developed a new surface modification method of $\mathrm{Fe}_{3} \mathrm{O}_{4}$, that is, the surface of $\mathrm{Fe}_{3} \mathrm{O}_{4}$ is modified by mesenchymal stem cell membrane (MSCM) after it is coated with PDA. Compared with $\mathrm{Fe}_{3} \mathrm{O}_{4} @ P D A p a r t i c l e s$, this modified method has better biocompatibility and less lung damage. In addition, we also explored the mechanism of lung injury induced by $\mathrm{Fe}_{3} \mathrm{O}_{4}$. MSCMmodification apparently avoided most of the autophagy induced by $\mathrm{Fe}_{3} \mathrm{O}_{4}$, and the autophagy related AMPK-ULK1 pathway activation was obviously lower.

\section{Materials And Methods}

\section{Preparation of $\mathrm{Fe}_{3} \mathrm{O}_{4}$ and $\mathrm{Fe}_{3} \mathrm{O}_{4} @ P D A$}

$\mathrm{Fe}_{3} \mathrm{O}_{4}$ nanoparticles stabilized by oleic acid were prepared by thermal decomposition method. In short, $2 \mathrm{mM}$ of iron acetylacetonate, $5 \mathrm{mM}$ of 1,2-hexadecanediol, $6 \mathrm{mM}$ of oleic acid and $6 \mathrm{mM}$ of oleyl ammonia were mixed in $20 \mathrm{~mL}$ of dibenzyl ether and mixed under nitrogen for $15 \mathrm{~min}$, and then heated to $200{ }^{\circ} \mathrm{C}$. After 30 min of reaction, it was vortexed at $265{ }^{\circ} \mathrm{C}$ for another $30 \mathrm{~min}$ and cooled to room temperature. The oleic acid-stabilized $\mathrm{Fe}_{3} \mathrm{O}_{4}$ nanoparticles were separated by a magnet, then washed with n-hexane and ethanol back precipitation three times, and then dispersed in toluene. Then disperse Fe304 nanoparticles and super particles in Tris buffer solution (10mM, pH8.5), add PDA hydrochloride monomer and stir for $3 \mathrm{~h}$, and then wash the centrifugal washing to remove excess self-polymerized dopamine in the solution to obtain $\mathrm{Fe}_{3} \mathrm{O}_{4} @ P D A$ superparamagnetic nanoparticles.

\section{Preparation of Cells and $\mathrm{MSCM}-\mathrm{Fe}_{3} \mathrm{O}_{4} @ \mathrm{PDA}$}

MSCs were purchased from American Type Culture Collection (Manassas, VA, USA). They were cultured in DMEM a supplemented with $10 \% \mathrm{FBS}$ in a humidified atmosphere of $5 \% \mathrm{CO}_{2}$ at $37^{\circ} \mathrm{C}$. The suspended cells were washed 3 times with PBS and centrifuged. Then, the cell pellet was suspended in a mixture of $225 \mathrm{mM}$ d-mannitol, $20 \mathrm{mM}$ Tris- $\mathrm{HCl}$ (pH 7.5), $75 \mathrm{mM}$ sucrose and $0.2 \mathrm{mM}$ EGTA for 24 hours to allow them to completely dissolve. The cells were then disrupted using a Dounce homogenizer at $4{ }^{\circ} \mathrm{C}$. After centrifuging at $3500 \mathrm{~g}$ for $5 \mathrm{~min}$ at $4{ }^{\circ} \mathrm{C}$, the supernatant was kept and centrifuged at $20,000 \mathrm{~g}$ for $30 \mathrm{~min}$ at $4{ }^{\circ} \mathrm{C}$. The supernatant was discarded and the membrane of MSCs was collected as an off-white precipitate for subsequent experiments. The MSCM were fully dispersed in PBS, and cell membrane vesicles were prepared using Avanti micro extruder. MSCM vesicles and $\mathrm{Fe}_{3} \mathrm{O}_{4} @ P D A$ core were mixed at a weight ratio of polymer to membrane protein of 2: 1 and coextruded through a PDA membrane with a pore size of $200 \mathrm{~nm}$ for 10 times to obtain $\mathrm{MSCM}-\mathrm{Fe}_{3} \mathrm{O}_{4} @ P D A$.

\section{Animal experiment}

As shown in Figure.1, 48 ICR mice weighing 18-22 g were purchased from SPF Biotechnology (Beijing, China) and were randomized into four groups: saline, $\mathrm{Fe}_{3} \mathrm{O}_{4}, \mathrm{Fe}_{3} \mathrm{O}_{4} @ P D A$ and $\mathrm{MSCM}-\mathrm{Fe}_{3} \mathrm{O}_{4} @ P D A$ exposure groups. Drug was injected into mice via tail vein. The dosage of $\mathrm{Fe}^{3+}$ was $45 \mathrm{mg} / \mathrm{kg} . \mathrm{kw} / \mathrm{d}\left(1 / 10 \mathrm{LD}_{50}\right)$.After four weeks, the mice were euthanized. According to the previously described method, the lungs were taken out and lavaged using 500 
$\mu \mathrm{L}$ PBS for three times to obtain a total of $1500 \mu \mathrm{L}$ of bronchoalveolar lavage fluid (BALF). Then half of the lungs of each group were stored at -80 degrees to extract protein and mRNA, and the rest were fixed with $4 \%$ formalin and stored at room temperature for staining.

\section{H\&E staining}

Paraffin sectionswere dewaxed to water, dyed with Harris hematoxylin for 3-8 min and washed with water.Then the sectionswere immersed $1 \%$ Hydrochloric acid alcohol for several seconds and washed with water.Next, the sections were dyed in eosin solution for 1-3 min, then dehydrated gradiently and sealed with gum. The sections were observed under microscope and the images were collected.

\section{Western blotting}

The mice lung tissues were lysed with ice-cold RIPA lysis buffer containing phosphatase-protease inhibitor cocktails (Beyotime Biotechnology, Shanghai, China). The concentration of protein was measured by BCA Protein Assay Kit (Beyotime Biotechnology, Shanghai, China). Equal amounts of protein lysates were subjected to SDS gel electrophoresis, immunoblotted with primary antibodies, and then the matched secondary antibodies. Western blot results were quantified by using the Image $\mathrm{J}$ software. Antibodies:Bax Rabbit Polyclonal antibody (Proteintech, CN, 50599-2-lg); Bcl-2 Rabbit Polyclonal antibody (Proteintech, CN, 12789-1-AP); Cleaved Caspase-3 Rabbit Polyclonal antibody (Cell Signaling Technology, US, 9664); Cleaved Caspase-9 Mouse Polyclonal antibody (Cell Signaling Technology, US, 9509); Beclin1 Rabbit Polyclonal antibody (Proteintech, CN, 11306-1-AP); P62 Rabbit Polyclonal antibody (Proteintech, CN,18420-1-AP); LC3 Rabbit Polyclonal antibody (Proteintech, CN,14600-1-AP); LC3-II Rabbit Polyclonal antibody (Cell Signaling Technology, US, 3868); p-AMPK Rabbit Polyclonal antibody (Cell Signaling Technology, US, 4186); AMPK Rabbit Polyclonal antibody (Proteintech, CN, 10929-2-AP);p-ULK1 Rabbit Polyclonal antibody (Cell Signaling Technology, US,37762); ULK1 Rabbit Polyclonal antibody (Proteintech, CN, 20986-1-AP).

\section{RNA isolation and qRT-PCR}

Total RNA was extracted from tissues using TRIzol (Invitrogen) following the manufacturer's instructions. $1 \mathrm{mg}$ of total RNA was subjected to reverse transcription using the One-Step cDNA Synene, Beijing, China) was used for RTqPCR. The PCR primer sequences are shown as Table 1.

\section{Table 1 Primers Used for qPCR}




\begin{tabular}{|lll|}
\hline Target gene & Direction & Sequence \\
Bcl-2 & Forward & CAGAGGGGCTACGAGTGGGATG \\
\cline { 2 - 3 } Bax & Reverse & TGGGTTGCTCTCAGGCTGGAAG \\
& Forward & TGCTGACGTGGACACGGACTC \\
\cline { 2 - 3 } AMK & Reverse & AGCAAAGTAGAAGAGGGCAACCAC \\
& Forward & ACACGGGAGGGTTGAAGAGG \\
ULK1 & Foverse & AGAATCTGCTGGAAGAGCCG \\
& Reverse & TCTGGTACGGGTACTCTGGG \\
B-actin & Forward & CACCCGCGAGTACAACCTTC \\
& Reverse & CCCATACCCACCATCACACC \\
\hline
\end{tabular}

\section{Immunocytochemistry}

Tissue slides were deparaffinized and rehydrated, then incubated with primary antibodies overnight at $4{ }^{\circ} \mathrm{C}$. Next, the sections were incubated with matched secondary antibody for 30 minutes at room temperature, stained with $\mathrm{DAB}$, and counterstained with hematoxylin.

\section{Statistical analysis}

All statistical analyses were carried out using the SPSS 19.0 statistical software package (SPSS Inc., Chicago, IL, USA). The data were presented as the mean \pm standard deviation (SD) at least three independent experiments. For the analysis of IHCpictures, 5 visual fields were randomly selected to take photos, and the average score was calculated.Data were analyzed using one-way analysis of variance for comparison between groups. $p<0.05$ was statistically significant.

\section{Results}

\section{Characterization of $\mathrm{Fe}_{3} \mathrm{O}_{4}, \mathrm{Fe}_{3} \mathrm{O}_{4} @ P D A$ and $\mathrm{MSCM}-\mathrm{Fe}_{3} \mathrm{O}_{4} @ P D A$}

Through TEM observation, $\mathrm{Fe}_{3} \mathrm{O}_{4}, \mathrm{Fe}_{3} \mathrm{O}_{4} @ P D A$ and $\mathrm{MSCM}-\mathrm{Fe}_{3} \mathrm{O}_{4} @ P D A$ all showed uniform spherical structure, while $\mathrm{MSCM}-\mathrm{Fe}_{3} \mathrm{O}_{4} @ P D A$ camouflaged with MSCM showed spherical core-shell structure, which indicated that MSCM had successfully camouflaged on the surface of $\mathrm{Fe}_{3} \mathrm{O}_{4} @ P D A$ (Figure.2A).Compared with $\mathrm{Fe}_{3} \mathrm{O}_{4} @ P D A$, the average hydrodynamic diameter of $\mathrm{MSCM}-\mathrm{Fe}_{3} \mathrm{O}_{4} @ P D A$ increased from 70.6 $\pm 0.8 \mathrm{~nm}$ to $85.4 \pm 1.4 \mathrm{~nm}$, which was basically consistent with the results of TEM. The increase in diameter may be due to the thickness of MSCM produced by lipid bilayer (Figure.2B).

The protein bands of $\mathrm{Na}^{+}-\mathrm{K}^{+}$-ATPase and CXCR4 were clearly observed on the surface of $\mathrm{MSCM}-\mathrm{Fe}_{3} \mathrm{O}_{4} @ P D A$, the lysate of MSCs and the membrane of MSCs (Figure.2C). In addition, GAPDH bands were clearly observed in the cracking solution of MSCs, but almost no in the MSCM-Fe $\mathrm{O}_{4} @ P D A$ nanoparticles and MSCs membrane, which 
indicated the purity of MSCM, and confirmed that the surface of $\mathrm{Fe}_{3} \mathrm{O}_{4} @ P D A$ was successfully camouflaged by MSCM.

\section{Co-modification with MSCM and PDA prevents $\mathrm{Fe}_{3} \mathrm{O}_{4}$-induced lung injury in mice}

The total amount of protein and neutrophils in BALF can reflect the lung damage of mice. As shown in Table 2, we found that compared with $\mathrm{Fe}_{3} \mathrm{O}_{4}$ group, the amount of total protein and neutrophils in BALF of $\mathrm{Fe}_{3} \mathrm{O}_{4} @ P D A g r o u p$

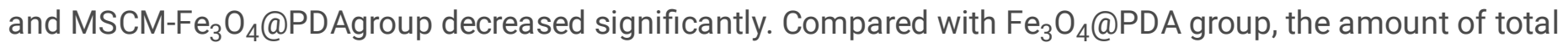
protein and neutrophil number of $\mathrm{MSCM}-\mathrm{Fe}_{3} \mathrm{O}_{4} @ P D A$ were more reduced.We then measured the level of inflammatory factors in BALF. The ELISA assay showed that the expression of IL- 6 and IL-8 in mice exposed to $\mathrm{Fe}_{3} \mathrm{O}_{4}$ increased significantly, while the level of inflammatory factors induced in $\mathrm{Fe}_{3} \mathrm{O}_{4} @ P D A$ group, and further decreased inMSCM- $\mathrm{Fe}_{3} \mathrm{O}_{4} @ P D A$ group. The results showed that the co-modification of MSCM and PDA increased the biocompatibility of $\mathrm{Fe}_{3} \mathrm{O}_{4}$ nanoparticles and reduced lung injury in mice.

\section{Table 2 Detection of inflammatory factors in BALF of mice (mean $\pm s d)$}

\begin{tabular}{|llllll|}
\hline Factors & $\begin{array}{l}\text { Total protein } \\
\text { concentration }\end{array}$ & $\begin{array}{l}\text { Number of } \\
\text { neutrophils }\end{array}$ & $\begin{array}{l}\mathrm{IL}-6 \\
(\mathrm{pg} / \mathrm{mL})\end{array}$ & $\begin{array}{l}\mathrm{IL}-8 \\
(\mathrm{pg} / \mathrm{mL})\end{array}$ & $\mathrm{TNF}-\mathrm{a}(\mathrm{pg} / \mathrm{mL})$ \\
\hline Saline & $98.33 \pm 8.50$ & $4536.67 \pm 152.88$ & $1.72 \pm 0.17$ & $1.70 \pm 0.29$ & $4.08 \pm 0.43$ \\
\hline $\mathrm{Fe}_{3} \mathrm{O}_{4}$ & $497.00 \pm 9.54^{\mathrm{a}}$ & $23153.67 \pm 530.10^{\mathrm{a}}$ & $72.82 \pm 7.64^{\mathrm{a}}$ & $55.16 \pm 3.81^{\mathrm{a}}$ & $106.76 \pm 6.64^{\mathrm{a}}$ \\
\hline $\mathrm{Fe}_{3} \mathrm{O}_{4} @ P D A$ & $437.67 \pm 8.33^{\mathrm{ab}}$ & $15758.00 \pm 1642.74^{\mathrm{ab}}$ & $52.54 \pm 5.09^{\mathrm{ab}}$ & $35.52 \pm 4.73^{\mathrm{ab}}$ & $83.94 \pm 2.80^{\mathrm{ab}}$ \\
\hline $\begin{array}{l}\mathrm{MSCM}^{\mathrm{F}} \\
\mathrm{Fe}_{3} \mathrm{O}_{4} @ P D A\end{array}$ & $392.67 \pm 20.53^{\mathrm{abc}}$ & $11287.33 \pm 781.47^{\mathrm{abc}}$ & $19.18 \pm 4.50^{\mathrm{abc}}$ & $19.55 \pm 0.79^{\mathrm{abc}}$ & $34.39 \pm 10.91^{\mathrm{abc}}$ \\
\hline $\begin{array}{l}\text { Fvalue } \\
\text { v value }\end{array}$ & 576.68 & 203.00 & 117.89 & 165.20 & 151.97 \\
\hline
\end{tabular}

(a: Significant compared with the Saline group; b: Significant compared with the $\mathrm{Fe}_{3} \mathrm{O}_{4}$ group; c:Significant compared with the $\mathrm{Fe}_{3} \mathrm{O}_{4} @ P D A$ group)

\section{Co-modification with $\mathrm{MSCM}$ and PDA prevents $\mathrm{Fe}_{3} \mathrm{O}_{4}$-induced apoptosis of lung tissue}

HE staining was used to detect the pathological morphology of the lungs of mice (Figure.3A). The results showed that $\mathrm{Fe}_{3} \mathrm{O}_{4}$ induced significant pathological changes in the alveoli of mice, including thickening of alveoli, hemorrhage and edema of alveoli, and infiltration of inflammatory cells. No pathological changes were observed in the lungs of mice exposed to $\mathrm{MSCM}-\mathrm{Fe}_{3} \mathrm{O}_{4} @ P D A$. We then used TUNEL staining to detect the apoptosis of lung cells in mice. The results showed that $\mathrm{Fe}_{3} \mathrm{O}_{4}$ significantly induced the apoptosis of mouse lung cells, PDA modification reduced the apoptosis rate, and MSCM modification further reduced the apoptosis of mouse lung cells (Figure.3B, Figure.3C).Western blotting (Figure.3D) and PCR (Figure.3E) showed that MSCM modification significantly inhibited the increase of $\mathrm{Bax}$ induced by $\mathrm{Fe}_{3} \mathrm{O}_{4}$. For $\mathrm{Bcl}-2, \mathrm{MSCM}-\mathrm{Fe}_{3} \mathrm{O}_{4} @ P D A$ significantly increased its expression, compared with $\mathrm{Fe}_{3} \mathrm{O}_{4} @ P D A$ group. 
We next performed IHC staning to detect the expression of apoptosis related proteins in mouse lung tissue (Figure.4A).The results showed that $\mathrm{Fe}_{3} \mathrm{O}_{4}$ significantly increased the expression of Bax (Figure.4B), Caspase-3 (Figure.4D) and Caspase-9 (Figure.4E), and decreased the expression of Bcl-2 (Figure.4C), which was consistent with our Western blot results. Compared with the $\mathrm{Fe}_{3} \mathrm{O}_{4} @ P D A$ group, $\mathrm{MSCM}-\mathrm{Fe}_{3} \mathrm{O}_{4} @ P D A$ group further reduced the increase of Bax and the decrease of Bcl-2. Those results show that co-modification with MSC and PDA prevents $\mathrm{Fe}_{3} \mathrm{O}_{4}$-induced apoptosis of lung tissue.

\section{Co-modification with MSCM and PDA prevents $\mathrm{Fe}_{3} \mathrm{O}_{4}$-induced autophagy of lung tissue}

It has been reported that nanoparticles lead to apoptosis by inducing autophagy. We then detected autophagy makers in the lung tissue of mice. It was found that $\mathrm{Fe}_{3} \mathrm{O}_{4}$ significantly increased the number of autophagic vesicles in mouse lung cells, while PDA decreased the number of autophagic vesicles, and MSCM further reduced the increase of autophagic vesicles (Figure.5A).Beclin1 is the key regulatory protein of autophagy. As shown in Figure.5B, we found that the expression of Beclin1 protein in the lungs of mice exposed to $\mathrm{Fe}_{3} \mathrm{O}_{4}$ increased significantly.Compared with the $\mathrm{Fe}_{3} \mathrm{O}_{4} @ P D A$ group, the expression of Beclin1 protein in the lungs of mice in the $\mathrm{MSCM}-\mathrm{Fe}_{3} \mathrm{O}_{4} @ P D A$ group decreased more obviously.P62 is an intracellular protein induced by stress and acts on selective autophagy.We found that the expression of p62 protein in lung of mice exposed to $\mathrm{Fe}_{3} \mathrm{O}_{4}$ decreased significantly, while the original level of p62 protein could be restored by MSCM modification.LC3 is a marker of autophagy. When autophagy is formed, cytoplasmic LC3 (LC3-I) will hydrolyze a small peptide and change into membrane type (LC3-II). The ratio of LC3-II/I can estimate the level of autophagy. We detected the LC3-II/I ratio of lung in four groups of mice by Western blotting. The results showed that $\mathrm{MSCM}-\mathrm{Fe}_{3} \mathrm{O}_{4} @ P D A$ significantly inhibited the increase of LC3-II/I ratio induced by $\mathrm{Fe}_{3} \mathrm{O}_{4} . \mathrm{IHC}$ staining (Figure.6A) of Beclin1 (Figure.6B), p62 (Figure.6C) and LC3-II(Figure.6D) protein in mouse lung was consistent with Western blot. These results indicate that comodification with MSCM and PDA prevents $\mathrm{Fe}_{3} \mathrm{O}_{4}$-induced autophagy of lung tissue.

\section{Co-modification with MSCM and PDA prevents $\mathrm{Fe}_{3} \mathrm{O}_{4}$-induced activation of AMPK-ULK1 axis}

Ulk1 complex can be used as a bridge between upstream energy sensing protein AMPK and downstream autophagy formation. Ulk1 is highly phosphorylated by AMPK, and then Beclin1 is activated, which is necessary for autophagy initiation. We then examined whether co-modification with MSCM and PDA attenuated $\mathrm{Fe}_{3} \mathrm{O}_{4}$ induced autophagy by interfering with the AMPK-ULK1 axis, a key regulatory pathway of autophagy. The results of Western blotting (Figure.7A) showed that there was no significant difference in the total protein levels of AMPK and ULK1 in the lung tissues among groups. However, $\mathrm{Fe}_{3} \mathrm{O}_{4}$ exposure significantly increased the phosphorylation level of AMPK and ULK1 protein in mice lungs, while PDA and MSCM modification significantly restored the phosphorylation level of AMPK and ULK1 protein. Compared with the $\mathrm{Fe}_{3} \mathrm{O}_{4} @ P D A$ group, the level of p-ULK1 protein in the lung of the $\mathrm{MSCM}-\mathrm{Fe}_{3} \mathrm{O}_{4} @ P D A$ group was further reduced. ThePCR results (Figure.7B) showed that the expression of AMPK and ULK1 mRNA was no significant affected among groups. The above results show thatco-modification with MSCM and PDA prevents $\mathrm{Fe}_{3} \mathrm{O}_{4}$-induced activation of AMPK-ULK1 axis.

\section{Discussion}

Iron oxide nanoparticles have gained extensive attention in biomedicine because of their excellent magnetic properties[18, 19].Tagged molecule can now be directed to a desired location with help of an external magnet[20]. Only precaution one has to take is to select a magnetic material having low toxicity and its ability for binding a 
biomolecules[21].Unfortunately, unmodified metal nanoparticles are often reported to have toxic effects, including hepatotoxicity[22, 23], nephrotoxicity[24, 25] and myocardial toxicity[26, 27]. In this study, we focused on the lung toxicity induced by $\mathrm{Fe}_{3} \mathrm{O}_{4}$ and how to use new modification methods to reduce the negative effects of $\mathrm{Fe}_{3} \mathrm{O}_{4}$.

The damage of nanoparticles to organs is usually caused by cell apoptosis.Apoptosis is mainly caused by the activation of caspase, a cysteine protease, by signal stimulation in vitro or intracellular[28]. Autophagy, like apoptosis, is an important physiological response of cells[29]. Under normal physiological conditions, autophagy remains at a low basic level, but it can be induced by some specific cell stress states[30].Autophagy may have different effects on cells. Under specific circumstances, autophagy can maintain cell survival, which is called protective autophagy[31], and sometimes autophagy can cause secondary apoptosis[32]. We injected $\mathrm{Fe}_{3} \mathrm{O}_{4}$ into the tail vein of mice and took out the lungs of mice four weeks later for observation. We found that $\mathrm{Fe}_{3} \mathrm{O}_{4}$ led to the destruction of mice lungs and the increase of apoptosis of lung cells. This is consistent with Stern's report[33]that demonstrated elevated levels of autophagic vacuoles upon exposure of cells to certain nanomaterials and the interaction between nanomaterials and the autophagy pathway is disruptive, resulting in obvious morphological changes and finally cell death.

In order to further push the limits of nanoparticle performance and function, a paradigm shift to a bionic design strategy has recently emerged[34]. A new class of biomimetic nanoparticle has been reported that combines the advantages of natural, cell membrane-derived vesicles with more traditional synthetic nanoparticulate platforms $[35,36]$. This new coating technology of grafting the cell membrane onto the surface of nanoparticles has pushed the nanomedicine to a new stage of development. The camouflaged nanoparticles can better adapt to the complex physiological environment[37]. Through homologous recognition, they can not only avoid the elimination of the immune system, but also greatly enhance the targeting characteristics, which has great application potential.

These particles generally employ a core-shell design, with a layer of cell membrane coated around a preformed nanoparticle core. Initially, membrane-coated nanoparticles were fabricated using a combination of red blood cell membrane and poly(lactic-co-glycolic acid), a biodegradable polymer, via a co-extrusion approach[38]In this experiment, we used the umbilical cord derived MSCM as a vesicle to wrap PDA modified $\mathrm{Fe}_{3} \mathrm{O}_{4}$ particles. Given the demonstrated low immunogenicity and strong targeting of stem cell membrane[39], we hypothesized that this new modification technology can greatly reduce the organ toxicity of $\mathrm{Fe}_{3} \mathrm{O}_{4}$ particles in vivo.

It is worth noting that mice injected with $\mathrm{Fe}_{3} \mathrm{O}_{4}$ particles coated with $\mathrm{MSCM}$ showed significantly lower lung injury, lower apoptosis and autophagy levels, which indicated that the co-modification of MSCM and PDA could significantly improve the biocompatibility of $\mathrm{Fe}_{3} \mathrm{O}_{4}$ particles modified by PDA alone.

Recently, it has been established that there is a direct link between AMPK, which is an energy sensor and is activated by glucose starvation[40], and ULK1 in triggering autophagy.Based on their doses and physico-chemical characteristics, nanoparticles have the capability of producing reactive oxygen species (ROS) or otherwise initiating signaling pathways that in addition to regulating autophagy, can eventually modulate different cell fates, including necrosis, necroptosis, apoptosis[41]. The intrinsic pathway of apoptosis is initiated by mitochondrial membrane permeabilization, various types of oxidative stress including hypoxia, DNA damage, and growth-factor deprivation[42]. Mitochondrial ROS production is a tightly regulated redox signal that transmits information from the organelle to the cell[43].It has been proposed that ROS can directly regulate AMPK activity independently of changes in adenine nucleotides[44, 45]. Our results show that MSCM can significantly reduce the activation of 
AMPK-ULK1 induced by $\mathrm{Fe}_{3} \mathrm{O}_{4}$ particles, which suggests that the protective effect of MSCM on mice lung may be achieved by reducing the level of oxidative stress, which should be discussed in the further experiments. Although PDA modification has attenuated the lung toxicity of $\mathrm{Fe}_{3} \mathrm{O}_{4}$ particles, we found that $\mathrm{Fe}_{3} \mathrm{O}_{4}$ particles encapsulated in stem cell membrane induce lower lung injury, autophagy and apoptosis than $\mathrm{Fe}_{3} \mathrm{O}_{4}$ particles modified by PDA alone.Thus, MSCM-coated Fe304@PDAmight be safely used for drug delivery and disease diagnosis.

\section{Conclusion}

In this study, we developed a new surface modification method of $\mathrm{Fe}_{3} \mathrm{O}_{4}$ particles, that is, $\mathrm{MSCM}$ was used to wrap $\mathrm{Fe}_{3} \mathrm{O}_{4} @ P D A p a r t i c l e s$, and proved its good biocompatibility through animal experiments.Co-modification with MSCM and PDA prevents $\mathrm{Fe}_{3} \mathrm{O}_{4}$-induced Pulmonary toxicity in mice by inhibiting the AMPK-ULK1 derived

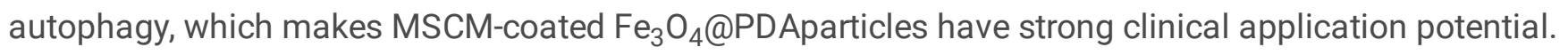

\section{Abbreviations}

MSCM, Mesenchymal stem cell membrane; PDA, polydopamine; PBS, phosphate buffer solution; BALF, bronchoalveolar lavage fluid; ELISA, enzyme linked immunosorbent assay; H\&E, hematoxylin-eosin; IHC, immunohistochemistry; TEM, transmission electron microscopy; SD, standard deviation;ROS, reactive oxygen species; AMPK, AMP-activated protein kinase; ULK1, unc-51 like autophagy activating kinase 1.

\section{Declarations}

\section{Acknowledgments}

This work was supported by the National Natural Science Foundation of China (Grant No. 81903273), the Jilin Province Science and Technology Development Plan Project (Grant No. 20190103078JH and 20190901007JC), the Science and Technology Project of Jilin Provincial Education Department (Grant No. JJKH20190073KJ and JJKH20190081KJ).

\section{Authors' contributions}

Te Liu, Jinlan Jiang conceived and designed the experiments; Te Liu, Hua Yao, Jun Yan, Pu Shao, Yuzhuo Wang, Tianxin Liu performed the experiments; Te Liu collected the data; Hua Yao, Jun Yan, Tianxin Liu analyzed the data; Te Liu wrote the paper. All authors checked and approved the final manuscript.

\section{Conflicts of interest}

The authors report no conflicts of interest in this work.

\section{Ethics approval and consent to participate}

All the experiments involved animals were meet the requirements. The animal experimental ethical inspection of this research was done by institutional animal care and use committee of Jilin University. The number of permit is KT201901003.

\section{Consent for publication}


Informed consent for publication was obtained from all participants. All the authors have agreed to publish this research.

Availability of data and materials

All data generated or analysed during this study are included in this published article. The datasets used or analysed during the current study are available from the corresponding author on reasonable request.

Funding

National Natural Science Foundation of China (Grant No. 81903273);

The Jilin Province Science and Technology Development Plan Project (Grant No. 20190103078JH and 20190901007JC);

The Science and Technology Project of Jilin Provincial Education Department (Grant No. JJKH20190073KJ and JJKH20190081KJ).

\section{References}

1. Wang G, Zhang X, Skallberg A, Liu Y, Hu Z, Mei X, Uvdal K: One-step synthesis of water-dispersible ultra-small Fe304 nanoparticles as contrast agents for T1 and T2 magnetic resonance imaging. Nanoscale 2014, 6:29532963.

2. Vangijzegem T, Stanicki D, Laurent S: Magnetic iron oxide nanoparticles for drug delivery: applications and characteristics. Expert Opin Drug Deliv 2019, 16:69-78.

3. Dunn AW, Ehsan SM, Mast D, Pauletti GM, Xu H, Zhang J, Ewing RC, Shi D: Photothermal effects and toxicity of Fe304 nanoparticles via near infrared laser irradiation for cancer therapy. Mater Sci Eng C Mater Biol Appl 2015, 46:97-102.

4. Khan MI, Mohammad A, Patil G, Naqvi SA, Chauhan LK, Ahmad I: Induction of ROS, mitochondrial damage and autophagy in lung epithelial cancer cells by iron oxide nanoparticles. Biomaterials 2012, 33:1477-1488.

5. Liu Y, Li X, Bao S, Lu Z, Li Q, Li CM: Plastic protein microarray to investigate the molecular pathways of magnetic nanoparticle-induced nanotoxicity. Nanotechnology 2013, 24:175501.

6. Lewinski N, Colvin V, Drezek R: Cytotoxicity of nanoparticles. Small 2008, 4:26-49.

7. Kobayashi N, Naya M, Endoh S, Maru J, Yamamoto K, Nakanishi J: Comparative pulmonary toxicity study of nano-TiO(2) particles of different sizes and agglomerations in rats: different short- and long-term postinstillation results. Toxicology 2009, 264:110-118.

8. Nishimori H, Kondoh M, Isoda K, Tsunoda S, Tsutsumi Y, Yagi K: Histological analysis of 70-nm silica particlesinduced chronic toxicity in mice. Eur J Pharm Biopharm 2009, 72:626-629.

9. Su Y, Xu JY, Shen P, Li J, Wang L, Li Q, Li W, Xu GT, Fan C, Huang Q: Cellular uptake and cytotoxic evaluation of fullerenol in different cell lines. Toxicology 2010, 269:155-159.

10. Gandamalla D, Lingabathula $\mathrm{H}$, Yellu N: Nano titanium exposure induces dose- and size-dependent cytotoxicity on human epithelial lung and colon cells. Drug Chem Toxicol 2019, 42:24-34.

11. Liu S, Zhu A, Chang X, Sun Y, Zhou H, Zou L, Su L: [Role of nitrative stress in nano nickel oxide-induced lung injury in rats]. Wei Sheng Yan Jiu 2016, 45:563-567. 
12. Lynge ME, Schattling P, Stadler B: Recent developments in poly(dopamine)-based coatings for biomedical applications. Nanomedicine (Lond) 2015, 10:2725-2742.

13. Fan X, Yuan Z, Shou C, Fan G, Wang H, Gao F, Rui Y, Xu K, Yin P: cRGD-Conjugated Fe304@PDA-DOX Multifunctional Nanocomposites for MRI and Antitumor Chemo-Photothermal Therapy. Int J Nanomedicine 2019, 14:9631-9645.

14. Wozniak A, Walawender M, Tempka D, Coy E, Zaleski K, Grzeskowiak BF, Mrowczynski R: In vitro genotoxicity and cytotoxicity of polydopamine-coated magnetic nanostructures. Toxicol In Vitro 2017, 44:256-265.

15. Song X, Gu X, Sun H, Fu C, Zhang Y, Dong P: Biomimetic Modification and In Vivo Safety Assessment of Superparamagnetic Iron Oxide Nanoparticles. J Nanosci Nanotechnol 2016, 16:4100-4107.

16. Bose RJ, Kim BJ, Arai Y, Han IB, Moon JJ, Paulmurugan R, Park H, Lee SH: Bioengineered stem cell membrane functionalized nanocarriers for therapeutic targeting of severe hindlimb ischemia. Biomaterials 2018, 185:360370.

17. Narain A, Asawa S, Chhabria V, Patil-Sen Y: Cell membrane coated nanoparticles: next-generation therapeutics. Nanomedicine (Lond) 2017, 12:2677-2692.

18. Martinkova P, Brtnicky M, Kynicky J, Pohanka M: Iron Oxide Nanoparticles: Innovative Tool in Cancer Diagnosis and Therapy. Adv Healthc Mater 2018, 7.

19. Laurent S, Forge D, Port M, Roch A, Robic C, Vander Elst L, Muller RN: Magnetic iron oxide nanoparticles: synthesis, stabilization, vectorization, physicochemical characterizations, and biological applications. Chem Rev 2008, 108:2064-2110.

20. Jurek PM, Zablocki K, Wasko U, Mazurek MP, Otlewski J, Jelen F: Anti-FGFR1 aptamer-tagged superparamagnetic conjugates for anticancer hyperthermia therapy. Int J Nanomedicine 2017, 12:2941-2950.

21. Mehta RV: Synthesis of magnetic nanoparticles and their dispersions with special reference to applications in biomedicine and biotechnology. Mater Sci Eng C Mater Biol Appl 2017, 79:901-916.

22. Sha B, Gao W, Wang S, Gou X, Li W, Liang X, Qu Z, Xu F, Lu TJ: Oxidative stress increased hepatotoxicity induced by nano-titanium dioxide in BRL-3A cells and Sprague-Dawley rats. J App/ Toxicol 2014, 34:345-356.

23. Yang B, Wang Q, Lei R, Wu C, Shi C, Yuan Y, Wang Y, Luo Y, Hu Z, Ma H, Liao M: Systems toxicology used in nanotoxicology: mechanistic insights into the hepatotoxicity of nano-copper particles from toxicogenomics. $J$ Nanosci Nanotechnol 2010, 10:8527-8537.

24. Lei R, Wu C, Yang B, Ma H, Shi C, Wang Q, Yuan Y, Liao M: Integrated metabolomic analysis of the nano-sized copper particle-induced hepatotoxicity and nephrotoxicity in rats: a rapid in vivo screening method for nanotoxicity. Toxicol Appl Pharmacol 2008, 232:292-301.

25. Uzar NK, Abudayyak M, Akcay N, Algun G, Ozhan G: Zinc oxide nanoparticles induced cyto- and genotoxicity in kidney epithelial cells. Toxicol Mech Methods 2015, 25:334-339.

26. Fang Y, Wang H, Dou HJ, Fan X, Fei XC, Wang L, Cheng S, Janin A, Zhao WL: Doxorubicin-loaded dextranbased nano-carriers for highly efficient inhibition of lymphoma cell growth and synchronous reduction of cardiac toxicity. Int J Nanomedicine 2018, 13:5673-5683.

27. Khosravi Y, Salimi A, Pourahmad J, Naserzadeh P, Seydi E: Inhalation exposure of nano diamond induced oxidative stress in lung, heart and brain. Xenobiotica 2018, 48:860-866.

28. Elmore S: Apoptosis: a review of programmed cell death. Toxicol Patho/ 2007, 35:495-516.

29. Ravanan P, Srikumar IF, Talwar P: Autophagy: The spotlight for cellular stress responses. Life Sci 2017, 188:5367. 
30. Kroemer G, Marino G, Levine B: Autophagy and the integrated stress response. Mol Cell 2010, 40:280-293.

31. Mathew R, Karantza-Wadsworth V, White E: Role of autophagy in cancer. Nat Rev Cancer 2007, 7:961-967.

32. Kasprowska-Liskiewicz D: The cell on the edge of life and death: Crosstalk between autophagy and apoptosis. Postepy Hig Med Dosw (Online) 2017, 71:825-841.

33. Stern ST, Johnson DN: Role for nanomaterial-autophagy interaction in neurodegenerative disease. Autophagy 2008, 4:1097-1100.

34. Vijayan V, Uthaman S, Park IK: Cell Membrane Coated Nanoparticles: An Emerging Biomimetic Nanoplatform for Targeted Bioimaging and Therapy. Adv Exp Med Biol 2018, 1064:45-59.

35. Xia Q, Zhang Y, Li Z, Hou X, Feng N: Red blood cell membrane-camouflaged nanoparticles: a novel drug delivery system for antitumor application. Acta Pharm Sin B 2019, 9:675-689.

36. Jiang Q, Liu Y, Guo R, Yao X, Sung S, Pang Z, Yang W: Erythrocyte-cancer hybrid membrane-camouflaged melanin nanoparticles for enhancing photothermal therapy efficacy in tumors. Biomaterials 2019, 192:292308.

37. Zou H, Zhu J, Huang DS: Cell membrane capsule: a novel natural tool for antitumour drug delivery. Expert Opin Drug Deliv 2019, 16:251-269.

38. Hu CM, Zhang L, Aryal S, Cheung C, Fang RH: Erythrocyte membrane-camouflaged polymeric nanoparticles as a biomimetic delivery platform. Proc Natl Acad Sci U S A 2011, 108:10980-10985.

39. Yang N, Ding Y, Zhang Y, Wang B, Zhao X, Cheng K, Huang Y, Taleb M, Zhao J, Dong WF, et al: Surface Functionalization of Polymeric Nanoparticles with Umbilical Cord-Derived Mesenchymal Stem Cell Membrane for Tumor-Targeted Therapy. ACS Appl Mater Interfaces 2018, 10:22963-22973.

40. Tamargo-Gomez I, Marino G: AMPK: Regulation of Metabolic Dynamics in the Context of Autophagy. Int J Mol Sci 2018, 19.

41. Abdal Dayem A, Hossain MK, Lee SB, Kim K, Saha SK, Yang GM, Choi HY, Cho SG: The Role of Reactive Oxygen Species (ROS) in the Biological Activities of Metallic Nanoparticles. Int J Mol Sci 2017, 18.

42. Cavalcante GC, Schaan AP, Cabral GF, Santana-da-Silva MN, Pinto P, Vidal AF, Ribeiro-Dos-Santos A: A Cell's Fate: An Overview of the Molecular Biology and Genetics of Apoptosis. Int J Mol Sci 2019, 20.

43. Scherz-Shouval R, Elazar Z: Regulation of autophagy by ROS: physiology and pathology. Trends Biochem Sci 2011, 36:30-38.

44. Shao D, Oka S, Liu T, Zhai P, Ago T, Sciarretta S, Li H, Sadoshima J: A redox-dependent mechanism for regulation of AMPK activation by Thioredoxin1 during energy starvation. Cell Metab 2014, 19:232-245.

45. Auciello FR, Ross FA, Ikematsu N, Hardie DG: Oxidative stress activates AMPK in cultured cells primarily by increasing cellular AMP and/or ADP. FEBS Lett 2014, 588:3361-3366.

\section{Figures}




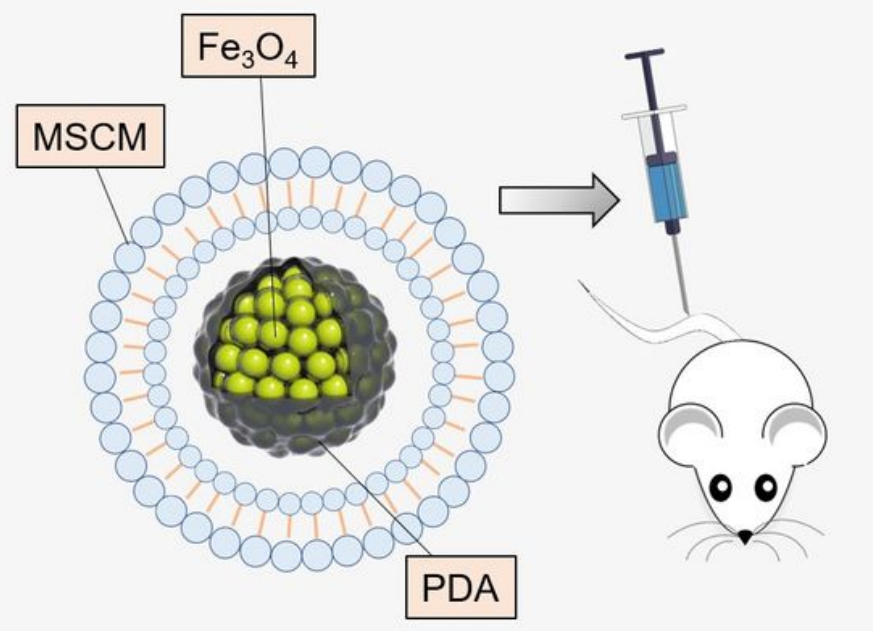

Day 1

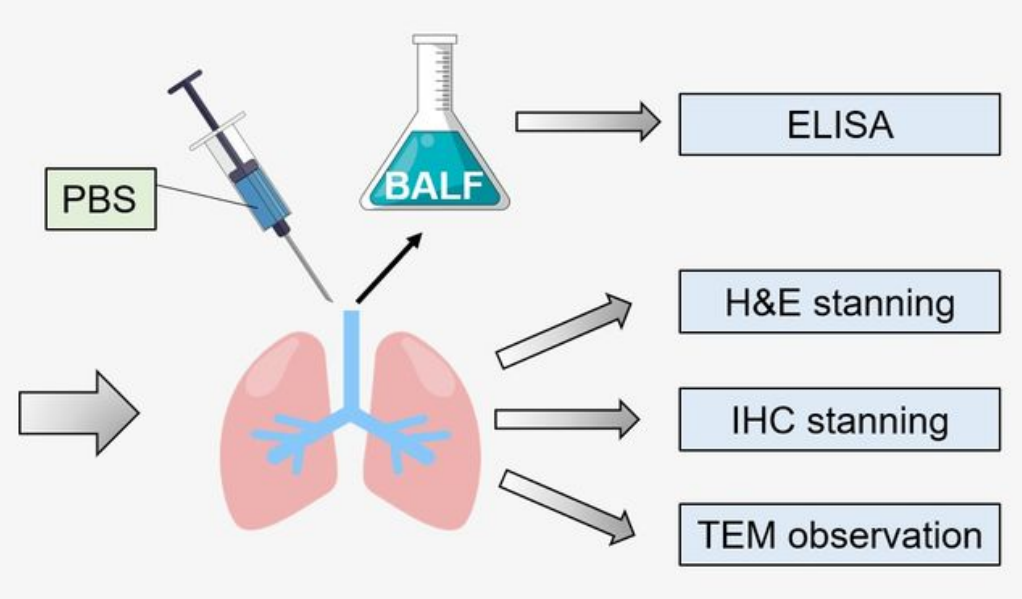

Day 28

\section{Figure 1}

As shown in Figure.1, 48 ICR mice weighing 18-22 $\mathrm{g}$ were purchased from SPF Biotechnology (Beijing, China) and were randomized into four groups: saline, Fe304, Fe304@PDA and MSCM-Fe304@PDA exposure groups. Drug was injected into mice via tail vein. The dosage of Fe3+ was $45 \mathrm{mg} / \mathrm{kg} . \mathrm{kw} / \mathrm{d}$ (1/10 LD50).After four weeks, the mice were euthanized. According to the previously described method, the lungs were taken out and lavaged using $500 \mu \mathrm{L}$ PBS for three times to obtain a total of $1500 \mu \mathrm{L}$ of bronchoalveolar lavage fluid (BALF). Then half of the lungs of each group were stored at -80 degrees to extract protein and mRNA, and the rest were fixed with $4 \%$ formalin and stored at room temperature for staining. 

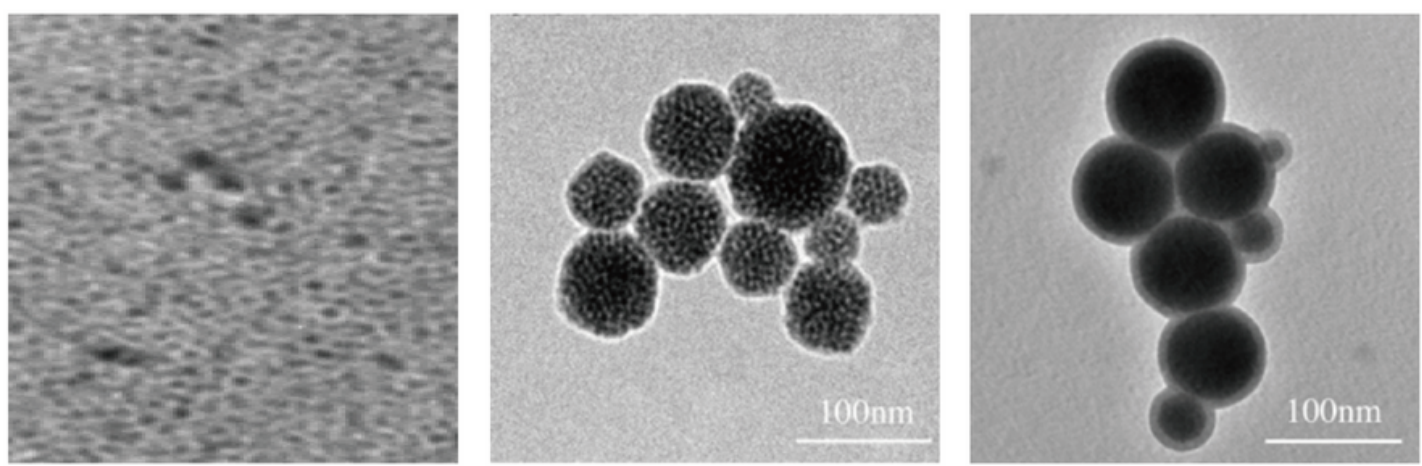

B

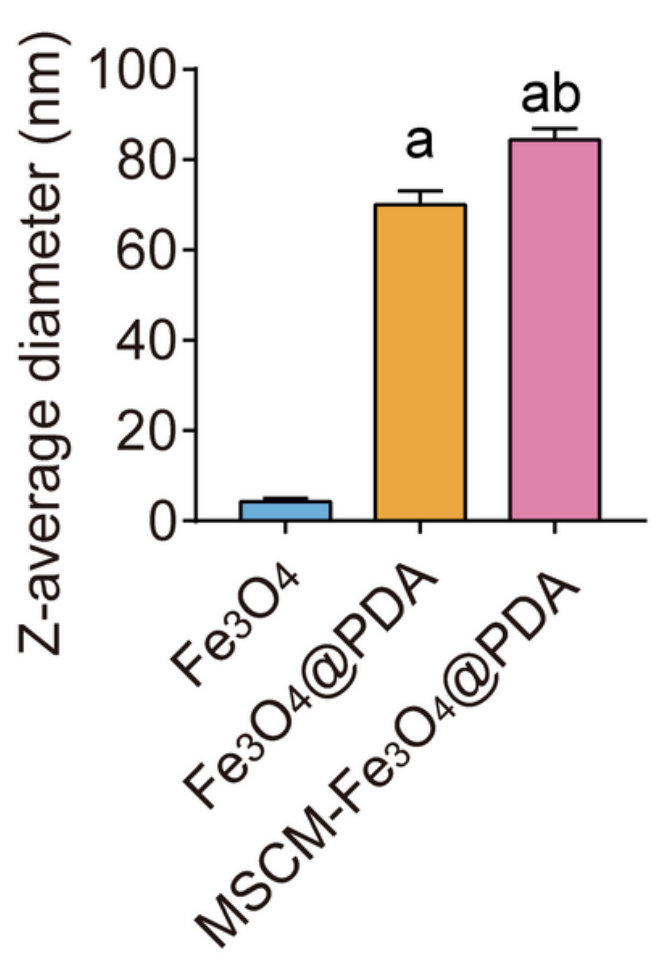

C

\section{CXCR4}

$\mathrm{Na}^{+}-\mathrm{K}^{+}-$

ATPase

GAPDH

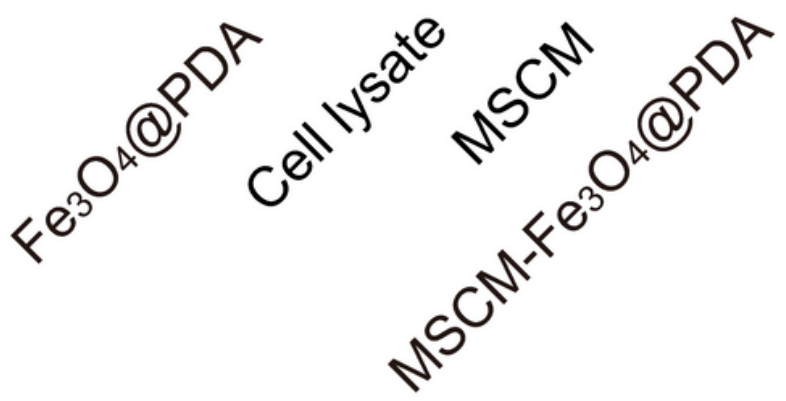

Figure 2

Through TEM observation, Fe304, Fe304@PDA and MSCM-Fe304@PDA all showed uniform spherical structure, while MSCM-Fe304@PDA camouflaged with MSCM showed spherical core-shell structure, which indicated that MSCM had successfully camouflaged on the surface of Fe304@PDA (Figure.2A).Compared with Fe304@PDA, the average hydrodynamic diameter of MSCM-Fe304@PDA increased from 70.6 $\pm 0.8 \mathrm{~nm}$ to $85.4 \pm 1.4 \mathrm{~nm}$, which was basically consistent with the results of TEM. The increase in diameter may be due to the thickness of MSCM produced by lipid bilayer (Figure.2B). The protein bands of $\mathrm{Na}+\mathrm{K}+-\mathrm{ATP}$ ase and CXCR4 were clearly observed on the surface of MSCM-Fe304@PDA, the lysate of MSCs and the membrane of MSCs (Figure.2C). In addition, GAPDH bands were clearly observed in the cracking solution of MSCs, but almost no in the MSCM-Fe304@PDA nanoparticles and MSCs membrane, which indicated the purity of MSCM, and confirmed that the surface of Fe304@PDA was successfully camouflaged by MSCM. 
A

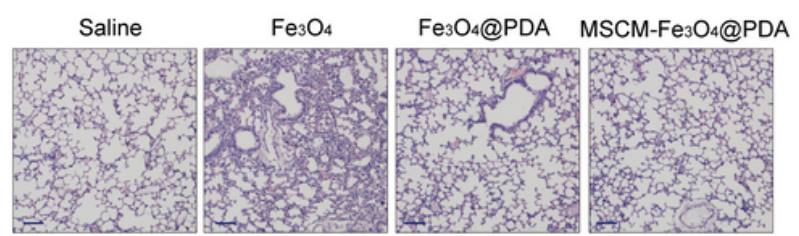

B
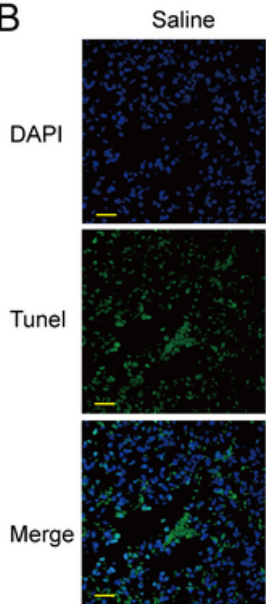

$\mathrm{Fe}_{3} \mathrm{O}_{4}$
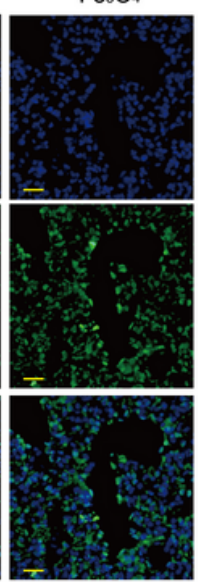
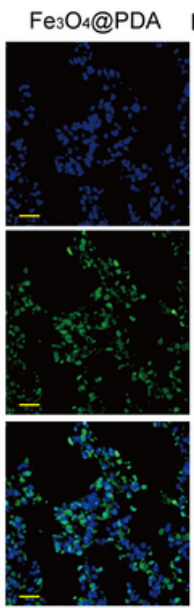

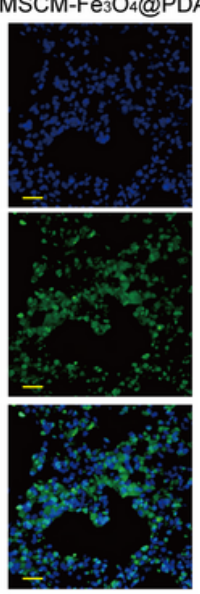

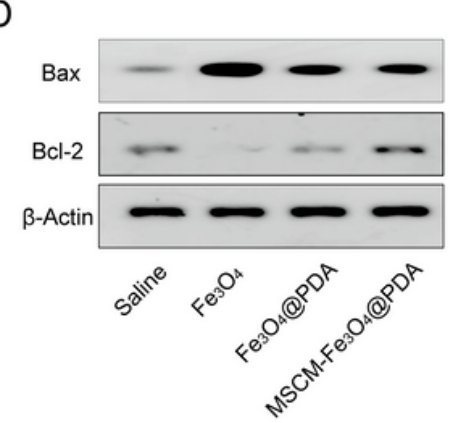
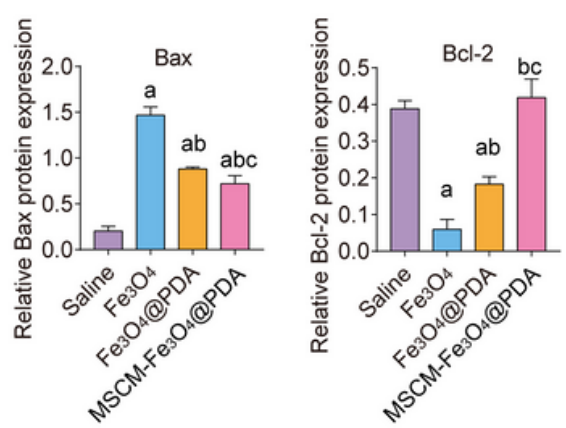

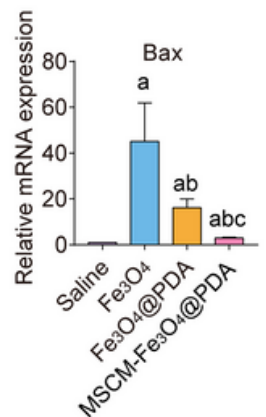

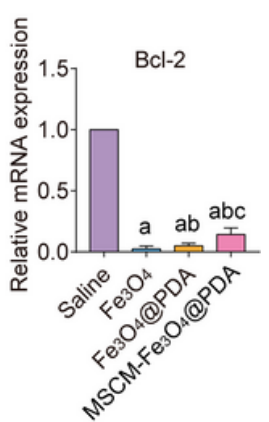

C

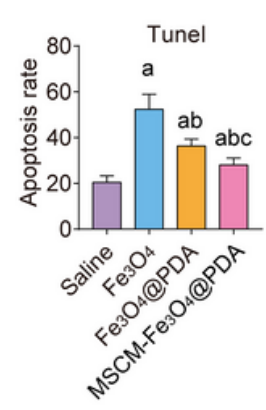

$\mathrm{E}$

Figure 3

HE staining was used to detect the pathological morphology of the lungs of mice (Figure.3A). The results showed that Fe304 induced significant pathological changes in the alveoli of mice, including thickening of alveoli, hemorrhage and edema of alveoli, and infiltration of inflammatory cells. No pathological changes were observed in the lungs of mice exposed to MSCM-Fe304@PDA. We then used TUNEL staining to detect the apoptosis of lung cells in mice. The results showed that Fe304 significantly induced the apoptosis of mouse lung cells, PDA modification reduced the apoptosis rate, and MSCM modification further reduced the apoptosis of mouse lung cells (Figure.3B, Figure.3C).Western blotting (Figure.3D) and PCR (Figure.3E) showed that MSCM modification significantly inhibited the increase of Bax induced by Fe304. For Bcl-2, MSCM-Fe304@PDA significantly increased its expression, compared with Fe304@PDA group. 

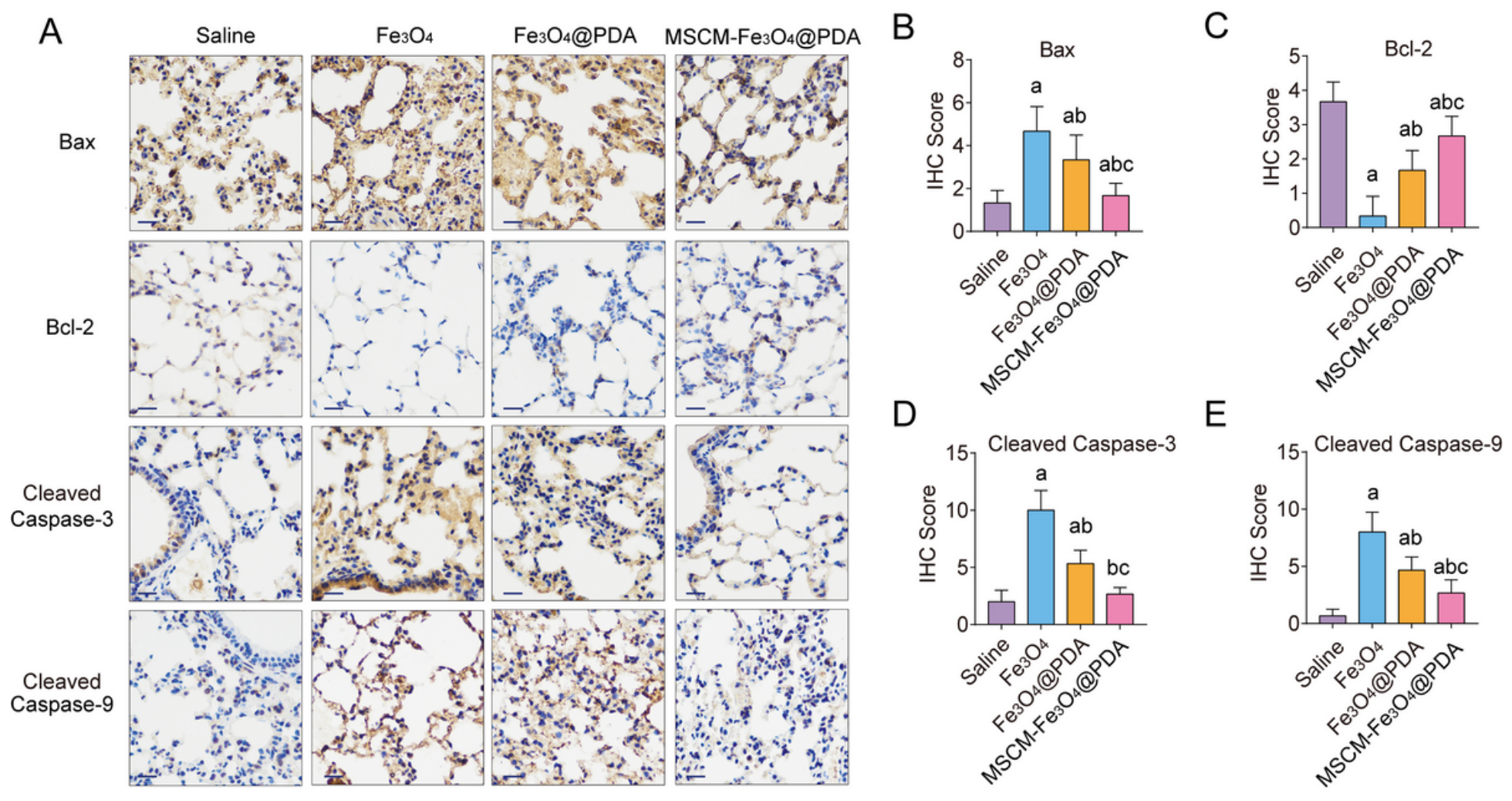

Figure 4

We next performed IHC staning to detect the expression of apoptosis related proteins in mouse lung tissue (Figure.4A).The results showed that Fe304 significantly increased the expression of Bax (Figure.4B), Caspase-3 (Figure.4D) and Caspase-9 (Figure.4E), and decreased the expression of Bcl-2 (Figure.4C), which was consistent with our Western blot results. Compared with the Fe304@PDA group, MSCM-Fe304@PDA group further reduced the increase of Bax and the decrease of Bcl-2. Those results show that co-modification with MSC and PDA prevents Fe304-induced apoptosis of lung tissue. 
A
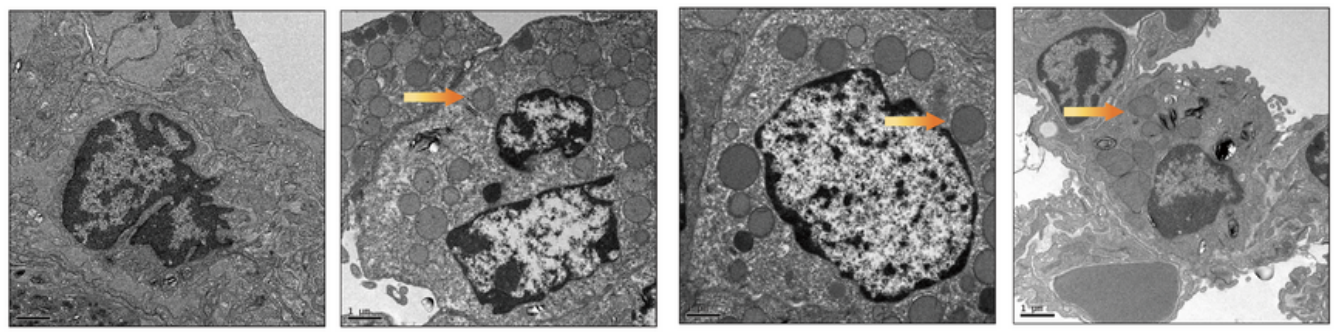

B
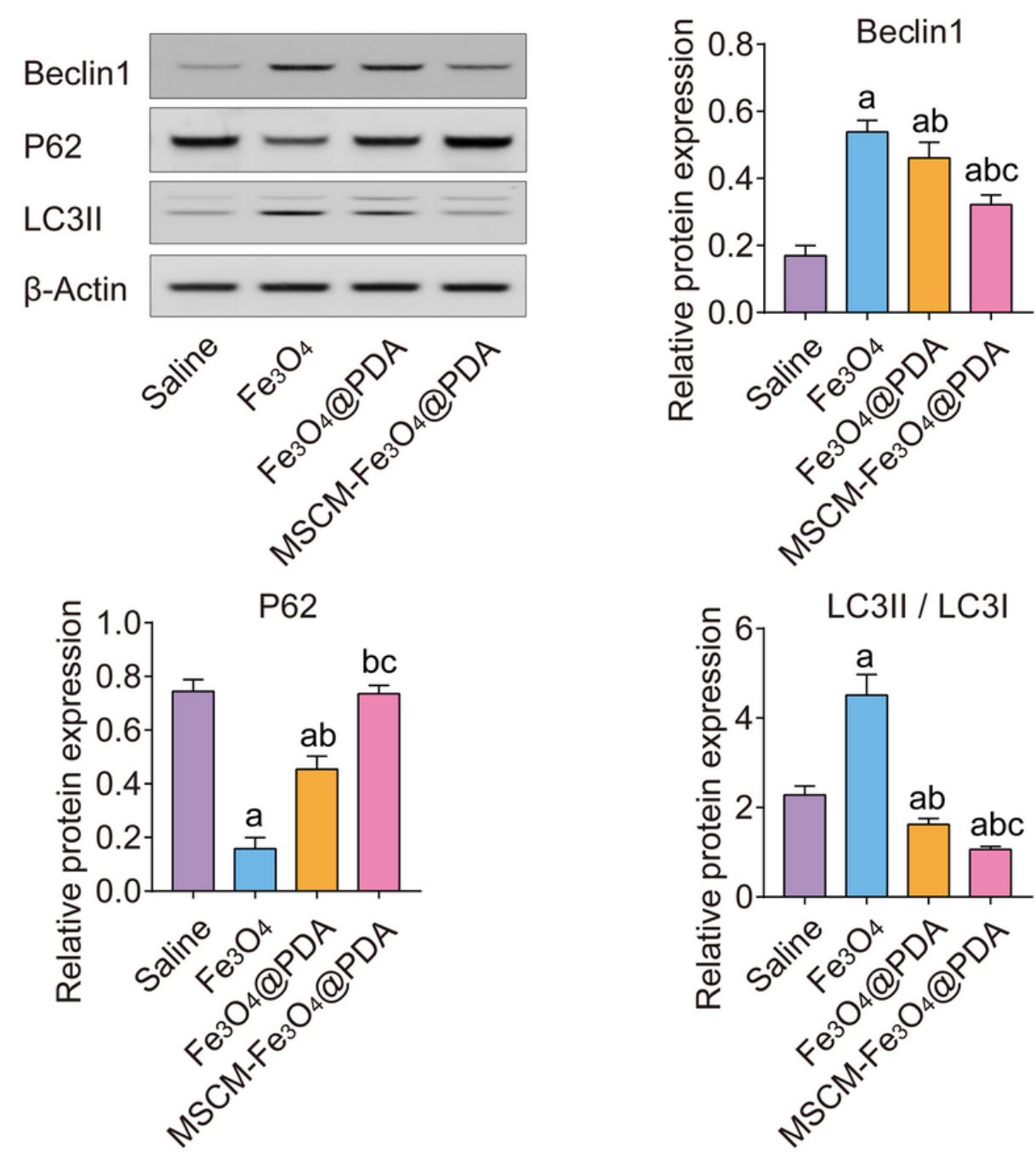

\section{Figure 5}

It has been reported that nanoparticles lead to apoptosis by inducing autophagy. We then detected autophagy makers in the lung tissue of mice. It was found that Fe304 significantly increased the number of autophagic vesicles in mouse lung cells, while PDA decreased the number of autophagic vesicles, and MSCM further reduced the increase of autophagic vesicles (Figure.5A).Beclin1 is the key regulatory protein of autophagy. As shown in Figure.5B, we found that the expression of Beclin1 protein in the lungs of mice exposed to Fe 304 increased significantly. 
A

$\mathrm{Fe}_{3} \mathrm{O}_{4}$

$\mathrm{Fe}_{3} \mathrm{O}_{4} @ \mathrm{PDA} \mathrm{MSCM}-\mathrm{Fe}_{3} \mathrm{O}_{4} @ \mathrm{PDA}$

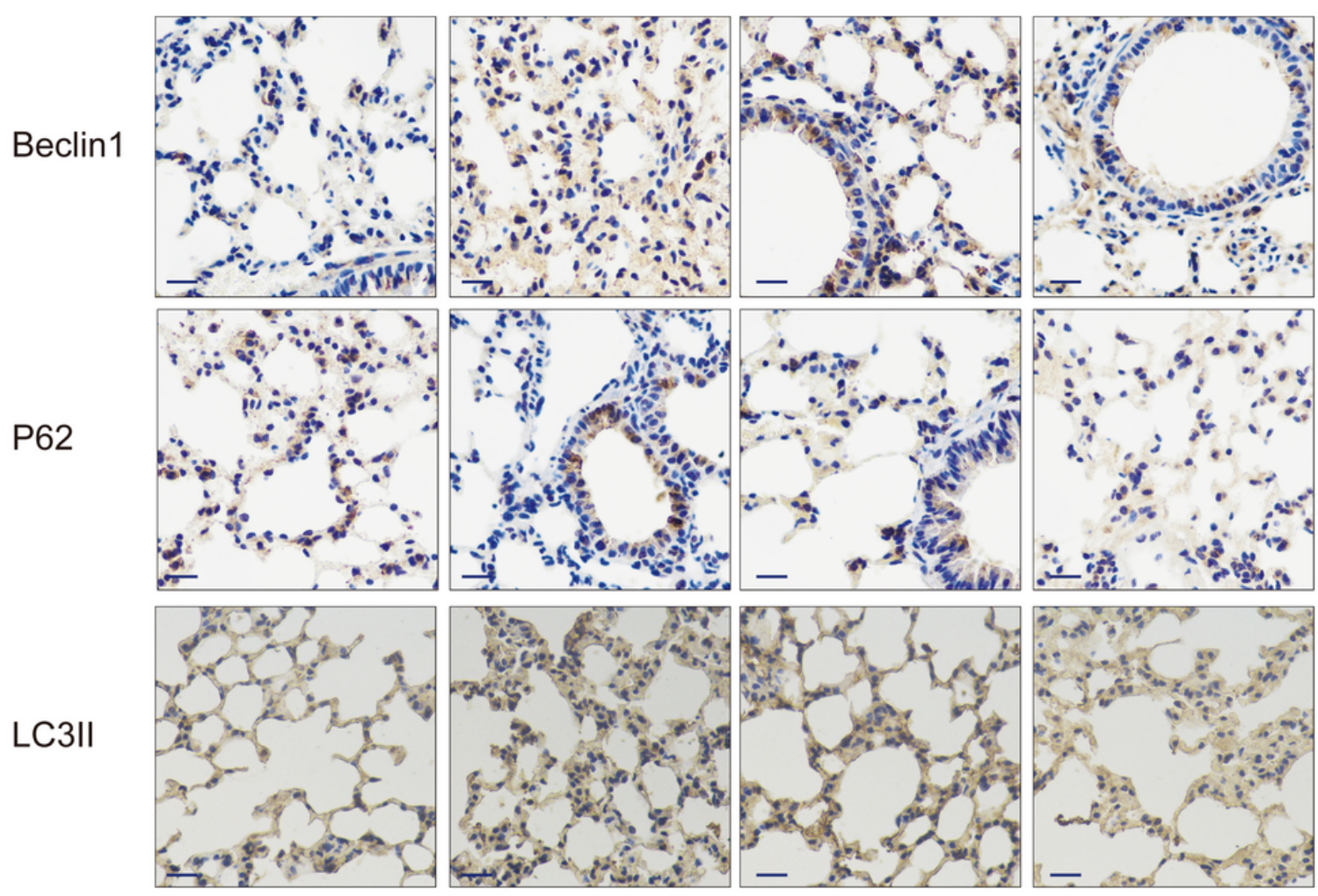

B

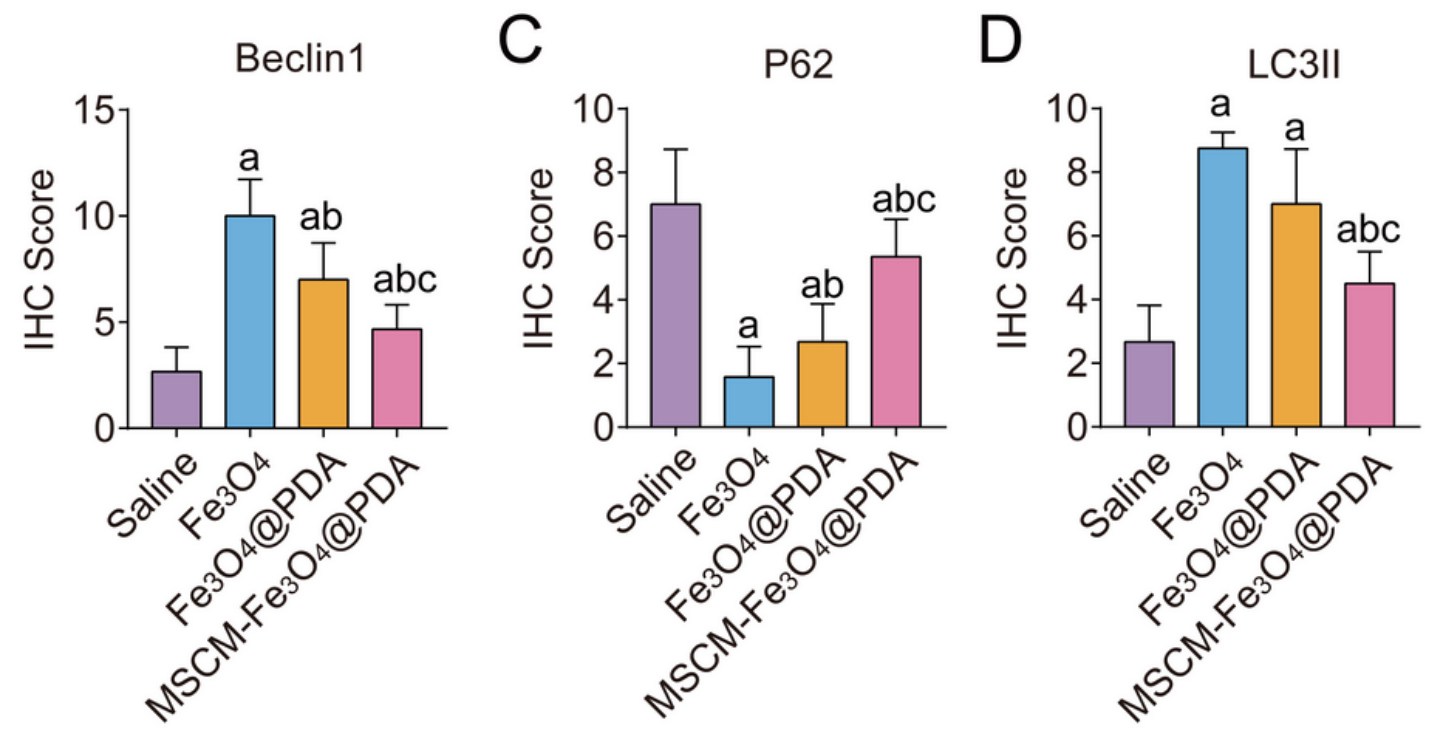

Figure 6

The results showed that MSCM-Fe304@PDA significantly inhibited the increase of LC3-II/I ratio induced by Fe304.IHC staining (Figure.6A) of Beclin1 (Figure.6B), p62 (Figure.6C) and LC3-II(Figure.6D) protein in mouse lung was consistent with Western blot. These results indicate that co-modification with MSCM and PDA prevents Fe304-induced autophagy of lung tissue. 


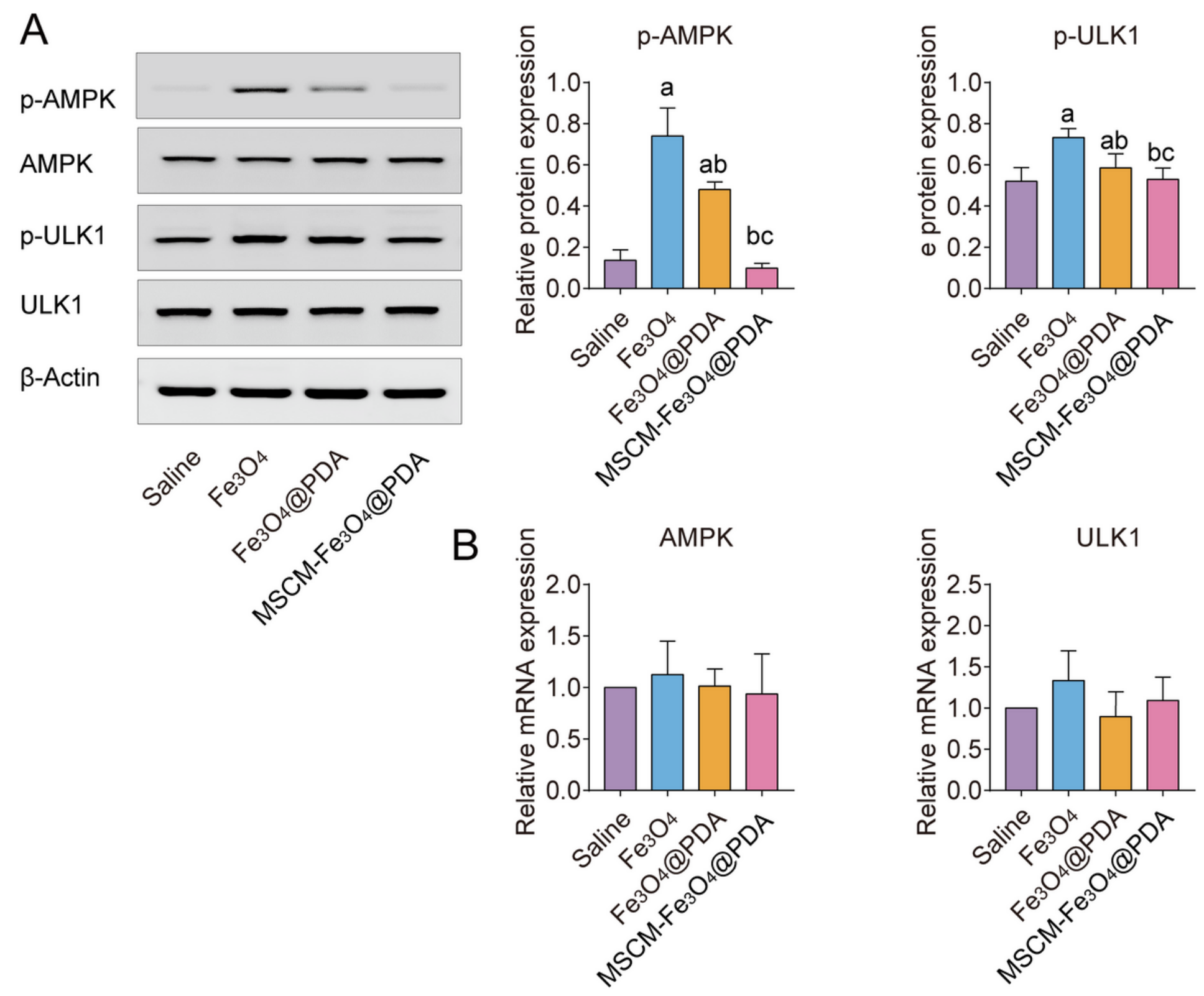

\section{Figure 7}

Ulk1 complex can be used as a bridge between upstream energy sensing protein AMPK and downstream autophagy formation. Ulk1 is highly phosphorylated by AMPK, and then Beclin1 is activated, which is necessary for autophagy initiation. We then examined whether co-modification with MSCM and PDA attenuated Fe304 induced autophagy by interfering with the AMPK-ULK1 axis, a key regulatory pathway of autophagy. The results of Western blotting (Figure.7A) showed that there was no significant difference in the total protein levels of AMPK and ULK1 in the lung tissues among groups. However, Fe304 exposure significantly increased the phosphorylation level of AMPK and ULK1 protein in mice lungs, while PDA and MSCM modification significantly restored the phosphorylation level of AMPK and ULK1 protein. Compared with the Fe304@PDA group, the level of p-ULK1 protein in the lung of the MSCM-Fe304@PDA group was further reduced. ThePCR results (Figure.7B) showed that the expression of AMPK and ULK1 mRNA was no significant affected among groups. The above results show thatco-modification with MSCM and PDA prevents Fe304-induced activation of AMPK-ULK1 axis. 